\title{
The Perception Toward Sore Ceria Program of RRI (Radio Republic of Indonesia) Tanjungkarang to Develop Teenagers' Interest in Radio Broadcasting
}

\author{
Muhammad Nasor ${ }^{1}$, Achlami $^{2}$, Siti Yuniarsih ${ }^{3}$ \\ \{nasor@radenintan.ac.id ${ }^{1}$, elangachlami@yahoo.co.id², amika.yunay97@gmail.com³
}

UIN Raden Intan Lampung, Indonesia ${ }^{123}$

\begin{abstract}
This study was aimed to identify the subjects' perception toward Sore Ceria program of RRI (Radio of the Republic of Indonesia) Tanjung Karang. The method used in this study was a descriptive qualitative method to obtain an overview of subjects' perception. The subjects were the students of the tenth-grade and the eleventh-grade of SMA Negeri 9 Bandar Lampung. The data that had been obtained through interview was then analyzed. The results of analysis showed that the subjects' perception can be categorized into the positive and negative perceptions. The Sore Ceria Program produced positive impression because it provided information and education. The subjects also stated that the program filled their free time and added new experiences. The gathering events held by this program also served as a mean of personal development and entertainment through radio broadcasting. The negative perceptions were caused by the frequent schedule changes, discrete personnel recruitment, and the Sore Ceria program is infrequently mentioned during the broadcasting.
\end{abstract}

Keywords: Teenagers' Perception, Sore Ceria Program, Develop Teenagers' Talent and Interest.

\section{Introduction}

Adolescence is the age of transition from childhood to adulthood which is the last development period in the development of personality or preparation for adulthood.[1] Teenagers must try to find their identity by facing certain situations that demand them to adjust not only to themselves but also to their environment so that teenagers can interact with themselves and the surrounding environment [2]. Teenagers who find their identity can ward off negative influences so that they can have good personality traits.[3] Such teenager behavior determines the quality of productive teenagers (15-64 years) in 2020-2030.[4] The youth will be the determinant of the nation's success because a nation is determined by the working-age and the quality of human resources, health, education, and skills as well as the improvement of soft skills so that they have global competitiveness.[5] Therefore, activities other than school are needed. One of which is radio broadcasting media through the Sore Ceria program. It is a segmented radio for young people (teenagers) initiated by Programa Dua (PRODUA). PRODUA RRI was developed as a center for creativity for young people.[6]

Sore Ceria program is the result of deliberations from the RRI (Radio of the Republic of Indonesia) that intends to involve the listeners directly in the broadcasting process which is segmented for teenagers. The ones who carry out the broadcasting programs or who become 
the broadcasters in the Sore Ceria program are students or teenagers. They are the students of senior high school and vocational high school in Bandar Lampung. Broadcasters are spokespersons for broadcast radio stations behind the studio's screen. Broadcasters also have duties and other assignments according to their skills.[7] Before the students could be the broadcasters, they must joint stages of workshops and training to develop their speaking skills, professional attitudes, mentality, communication skills, public speaking skills, self-confidence, and others. The training lasts from one month to three months of quarantine. The purpose is to explore students' knowledge or experience in the field of Broadcasting.[6] Broadcasting, according to Law No. 32 of 2002, is messages or series of messages in the form of sound, pictures, sounds, and pictures or in the form of graphics, characters, whether interactive or not, that can be received through a broadcast receiver.[8]

Normally, students do not get these lessons at school. Therefore, there is a need for facilities outside the school that provide a place to develop students' interest and talent, especially in broadcasting. The world of broadcasting is one of the many fields that can be a place for teenagers to find their identity in the community. Most teenagers nowadays are not regular listeners to radio. They may occasionally tune in, but they do not try to listen to a program specifically. The main reason teenagers listen to the radio is for music, but now with online sites streaming music for free they do not bother, as services such as last.fm do this advert free, and users can choose the songs they want instead of listening to what the radio presenter/DJ chooses. Radio listening among youngest teenagers is declining - but still holding up - and not every teenager is like every other teenager. [9] This phenomenon could decrease the teenagers' interest in listening to the radio. In order to promote the radio program, radio station should be aware of the demand and condition of the society.

The role of a broadcaster determines the success of a radio program. Whatever presenters say has a great impact on young people who relate to the issue at hand. They look up to and trust radio presenters very much. Thus, our radio station provides training to our presenters in order to create the best out there [10]. Selecting appropriate radio program and broadcasters is necessary in order to survive the market. This reason inspires RRI Bandar Lampung to present a program suited to the teenagers' need of updated information. The reason why teenagers, specifically those who are in the high school level of education, are chosen to be the broadcaster of the program because they could relate their life to the intended listeners. Starting from that, the writers believe that adolescence is an important period because it is where the process of finding identity begins. The writers intended to find out the teenagers' perception and what are their views on the existence of programs that provide opportunities for high school students to become broadcasters.

Radio broadcast is still relevant these days. The invasion of multimedia technology and internet could not bring a complete stop to the advancement of radio broadcasting. Radio broadcasts can provide information and entertainment broadcasted 24 hours a day to provide the most recent updates about news or something entertainment related to listeners. When there is no access to the internet, young people can still search the airwaves for trustworthy sources. Even electricity is not a necessity for battery operated and hand-cranked radios. [10]

Radio is rich in history. In its golden period, radio broadcast was a credible source of information that can be enjoyed by many people. Radio news was more than just a quick way to find out about events; it was a way for U.S. citizens to experience events with the same emotions. During the Ohio and Mississippi river floods of 1937, radio brought the voices of those who suffered as well as the voices of those who fought the rising tides. A West Virginia newspaper explained the strengths of radio in providing emotional voices during such crises: "Thanks to radio ... the nation as a whole has had its nerves, its heart, its soul exposed to the 
needs of its unfortunates ... We are a nation integrated and interdependent. We are 'our brother's keeper.[11]

Radio is effective in not only informing the youth, but also in creating awareness regarding many social issues and needs for social reformation, developing interest and initiating action, for example, introducing a new policy, development projects or creative ideas to the public. Having a radio around helps to create a positive climate for growth and development[10]. Several other researchers have discussed the students' perception, one of which was conducted by Darwis [12] [13]. He states that student's percept the podcast as an exciting activity although they hard to follow the broadcasting because the lack of tools.

Based on some of the above description, it can be understood that the writers intended to know the views of the SMA Negeri 9 Bandar Lampung students towards the Sore Ceria program in forming qualified teenagers in the field of broadcasting. Following the description above, the main problem discussed in this study is "How is the perception of teenagers towards the Sore Ceria Program of RRI Tanjungkarang?"

\section{Research Method}

This study employed the qualitative approach with the field-study method. It was aimed at describing and analyzing phenomena, events, social activities, attitudes, beliefs, perceptions, thoughts of individuals, individually or in groups.[14] Field research is a study conducted in a systematic and in-depth by collecting data in the field[15] to describe the characteristics of individuals, situations, or certain groups.[16] This method was used to get a description of the perceptions of teenagers or the tenth and eleventh-grade students of SMA Negeri 9 Bandar Lampung toward the Sore Ceria program of RRI Tanjungkarang in developing the interest and talent in the field of radio broadcasting.

The population of this study was all tenth and eleventh-grade students of SMA Negeri 9 Bandar Lampung. The population consisted of 806 students, specifically 361 male students and 445 female students. In determining the sample of the study, the writers used purposive sampling technique. The members of the population do not necessarily have the same opportunity to be selected as a sample, due to certain considerations.[16] The researchers set the sample of 15 students. Data collection technique used was interview. After the data had been deemed sufficient, the data collection was stopped and then the data was processed/analyzed.[17] The data analysis technique used was qualitative-descriptive analysis by describing and interpreting the data.

\section{Results and Discussion}

Sore Ceria is a radio program for students in Lampung to provide the broadcasting experience, especially as a radio broadcaster. This program has been around since 2002 until now. Its members consist of high school students. It can be enjoyed on the PRODUA RRI Tanjungkarang Bandar Lampung at 92.5 FM every Monday to Friday from 9 AM to 9 PM. The studio is located in the RRI Bandar Lampung Building, Gatot Subroto st. No.26 Bandar Lampung. In this program, several teen broadcasters are on air to deliver a program like professional radio broadcasters. This program is the first program that only exists in RRI Tanjungkarang Bandar Lampung and not yet in other RRI branches. 
The contents of the program are focused on culture, information, education, and entertainment which is packaged in an attractive manner typical of teenagers. Sore Ceria is aimed at accommodating high school students who like and have an interest in broadcasting. As for this community, recruitment is opened once a year. In 2019, the program has entered the 23 rd to 24 th generation wherein each recruitment, 25 to 30 teen broadcasters are accepted. The researchers interviewed the sample regarding their perception toward the Sore Ceria Program. Based on the results of the interview, several positive and negative opinions were obtained.

Table 1. Students Positive Perception toward the Sore Ceria Program

\begin{tabular}{cc}
\hline No & Positive Perception \\
\hline 1 & Informative \\
2 & Educative \\
3 & Enrich experience and fill leisure time \\
4 & Expanding the circle of friendship \\
5 & Means of self-development \\
\hline
\end{tabular}

Table 1 displays the students' positive perception toward Sore Ceria program. The first positive perception identified was that the presentation of the Sore Ceria was considered as good and informative. This positive perception could be obtained since the program presents a variety of themes. The material presented by the broadcasters is in the form of information that is packaged interestingly with a youthful speaking style. The information covers broad range of topics including science, technology, culture, and up-to-date news that most of the teenagers could relate. One example of the information delivered at the program was the newly launched social media, tourist spots that should be visited in Indonesia or abroad, as well as the top chart of music videos and movies. This program is very informative since it contains interesting information with the typical nature of teenagers and information in the form of cultural products that reflect the culture in society.

The second positive perception was that the Sore Ceria program was considered educative because the program often holds trainings for teenagers. During the training, starting from theory to practice, the materials taught were personal attitude (behavior), musical insight, performance, vocal, general knowledge, English, motivation and self-development, broadcasting techniques, public speaking, theater of the mind, broadcast aesthetics, and also a chance to collaborate with senior broadcasters. The contents of training added knowledge for the students who have the opportunity to become broadcasters because they could get an education on broadcasting that is unavailable at school. The learning materials taught at the trainings could also be utilized to support the knowledge and development of the students at school or their daily life. During the training, the students are taught how to pronounce English words and express their ideas in English that could also support their learning at school. Regarding the benefits of the training that could be applied in their daily life, personal attitude course during the training could also be applied for the personal growth of the students. There, they are taught how to appropriately speak to large audiences, how to maintain their emotion, and how to respond to the ever-changing courses of discussion. Their knowledge on music is also increased by studying the various genre of music and another musical knowledge.

The third positive perception was that the program enriched the teenagers' experience by providing opportunity to act as broadcasters. Through this program, additional experiences and activities to fill their valuable free time. The opportunity to be a radio broadcaster means that their public speaking skills are honed and also serve as a valuable experience that could 
not be acquired in classrooms. The fourth positive perception was that the program expanded the circle of friendship because the scope of the Sore Ceria program is quite wide which includes the students of senior high schools and vocational high schools in Lampung. Evidenced by the number of broadcasters that consisted of 23 students from different schools. Those who initially do not know each other can be acquainted although they come from different schools. Sore Ceria program is considered a means to promote students' selfdevelopment in the field of broadcasting, especially as a radio broadcaster. The broadcasting activities provide learning activities in broadcasting. It can also be a way to hone the students' talents, creativity, and skills in radio broadcasting.

Also, based on the obtained data, the Sore Ceria program is very positive for students to learn the world of broadcasting. The intended target audience was considered appropriate for teenagers. This program can entertain listeners when they are bored and sad. Entertainment that is often presented is music, info about celebrities, and plays or dramas. However, the subjects also expressed their negative impression toward the program. Based on the interview, the subjects' negative impression can be seen in table 2 .

Table 2. Students' Negative Perception toward the Sore Ceria Program

\begin{tabular}{cc}
\hline No & Negative Perception \\
\hline 1 & Limited recruitment information \\
2 & Infrequently mentioned program's name \\
3 & Schedule changes \\
\hline
\end{tabular}

Based on table 1, the first negative perception expressed by students was that the recruitment of the Sore Ceria broadcasters was limited. The open recruitment announcement of Sore Ceria has not been widespread among high school students. The information regarding the audition for broadcasters is not well-spread since many students do not aware of the recruitment. This is happening because the announcement for the audition is only published through the Instagram account. The students who have not to follow the Instagram account is deprived of the audition information. Another reason is the lack of socialization. Not all schools in Bandar Lampung were visited by the team. The second negative perception was that the broadcasters rarely mention the name of the program during their broadcasting sessions. They often mention other names, such as Produa Issue in each session.

The last negative perception was caused by the change of schedule. It originally aired from $3 \mathrm{PM}$ to $5 \mathrm{PM}$ now it is aired from $5 \mathrm{PM}$ to $7 \mathrm{PM}$. This information has not been known by many students because the announcement is only broadcasted through the Instagram account. It confuses listeners who don't know the schedule changes and have not followed the Instagram account. Based on the obtained and analyzed data, the teenagers' perception affected their interest in radio broadcasting. It was proven by the enthusiasm of the teenagers in joining the Sore Ceria program to temporarily be broadcasters. They also stated that the broadcasting activities can enrich someone's knowledge by providing interesting information. However, the changes of schedules and rarely mentioned program leave negative perception on the teenagers. 


\section{Conclusions}

Based on the results of study, it can be concluded that the subjects' perception were divided into two categorized, namely the positive and negative perceptions. In the positive perception, the Sore Ceria Program provided information and education. The subjects also stated that the program filled their free time and added new experiences. The gathering events held by this program also served as a mean of personal development and entertainment through radio broadcasting. The negative perceptions were caused by the frequent schedule changes, discrete personnel recruitment, and the Sore Ceria program is infrequently mentioned during the broadcasting.

\section{References}

[1] Sarlito W. Sarwono, Psikologi Remaja. Jakarta: Rajawali Pers, 2013.

[2] P. Nurbudi, Hubungan Harga Diri Dengan Motivasi Berprestasi Pada Remaja Panti Asuhan Harapan Kita Di Kota Bandung. Bandung: UIN Sunan Gunung Djati, 2017.

[3] M. Al-Mighwar, Psikologi Remaja. Bandung: Pustaka Setia, 2006.

[4] Y. Noormansyah, Analisis Dampak Bonus Demografi Terhadap Kesempatan Kerja di Indonesia. Bandung: Unpad Press, 2018.

[5] Yusmarni, "Analisis Bonus Demografi sebagai Kesempatan dalam Mengoptimalkan Pembangunan Pertanian di Sumatera Barat," Jurnal, vol. 16, no. 1, p. 67, 2016.

[6] Tim Radio Republik Indonesia, "Company Profile Radio Republik Indonesia,” 2006.

[7] R. R. Tirsyad, Strategi Komunikasi Penyiar I-Radio Makassar Dalam Program Sorelam, Skripsi. Makassar: UIN Alauddin, 2016.

[8] T. R. S. Utami, Dasar - Dasar Penyiaran. Malang: Universitas Dian Nuswantoro, 2016.

[9] R. McKenzie, "Teenagers' listening habits." .

[10] L. Mupetami, "The Importance of Radio in Educating Young People.".

[11] R. Brown, Manipulating the Ether: The Power of Broadcast Radio in Thirties America. Jefferson: NC: MacFarland, 1998.

[12] R. Darwis, "Students' Perceptions towards the Use of Podcast in Learning English: A Case Study of the Second Grade Students at One High School In Bandung," J. English Educ., vol. 4, no. 2, pp. 80-100, 2016.

[13] I. K. Sudarsana, W. Mahardika, I. W. Lali Yogantara, K. Saddhono, and D. Napitupulu, "Students' Perception of the Implementation of Blended Learning at Institut Hindu Dharma Negeri Denpasar," J. Phys. Conf. Ser., vol. 1114, no. 1, 2018.

[14] N. S. Sukmadinata, Metode Penelitian Pendidikan. BANDUNG: Remaja Rosdakarya, 2007.

[15] C. Narbuko and A. Achmadi, Metodelogi Penelitian. Jakarta: PT. Bumi Aksara, 2007.

[16] Abuddin Nata, Metodologi Studi Islam. Jakarta: Raja Grafindo Persada, 2001.

[17] Hadari Nawawi, Metode Penelitian Bidang Sosial. Yogyakarta: Gajahmada Universitas Pers, 2013. 